\title{
Discourses of Determinants Factor in Audit Quality
}

\author{
Erik Nugraha ${ }^{1}$, Lucky Nugroho ${ }^{2}$, Audita Setiawan ${ }^{3}$ \\ \{erik.nugraha@usbypkp.ac.id ${ }^{1}$, lucky.nugroho@mercubuana.ac.id ${ }^{2}$, \\ audita.setiawan@usbypkp.ac.id $\left.{ }^{3}\right\}$ \\ Universitas Sangga Buana, Indonesia ${ }^{1}$, Universitas Mercu Buana, Indonesia ${ }^{2}$, Universitas Sangga \\ Buana, Indonesia ${ }^{3}$
}

\begin{abstract}
Rapid business competition causes companies to improve the quality of products and services produced. In addition to improving the quality of its output, companies also need the services of a reliable auditor to examine financial statements so that they can be trusted with fairness. However, there is a phenomenon that the Public Accountant has not fully obtained sufficient and appropriate audit evidence and has not fully complied with the professional code of ethics in accepting and carrying out audit engagements. The purpose of this study is to find empirical evidence about the effect of audit evidence and enforcement of the code of ethics on audit quality, and to know the impact simultaneously, as well as partially. The research sample was taken using a purposive sampling technique that is as many as 54 public accountants in the city of Bandung, West Java-Indonesia. The statistical method used to test the hypothesis is multiple regression. The results of this study by using the test of the coefficient of determination obtained the value of the coefficient of determination or R-square of $23.8 \%$, which shows the variable that the audit evidence and ethics code enforcement variables simultaneously influence the audit quality variable. Furthermore, a partial test of audit evidence has a significant positive effect on audit quality, but the enforcement of a code of ethics does not affect audit quality.
\end{abstract}

Keywords: Audit Evidence, The Code of Ethics Enforcement, Audit Quality.

\section{Introduction}

Public Accountant Audit service is needed by outside parties, and this is because the audit is often seen as an assurance service, that is, independent professional services that can improve the quality of information for decision-makers. For the profession of public accountants, it is essential that the client and external parties of the financial report users have confidence in the quality of the audit produced by the Public Accountant Office (KAP) (1).

A public accountant is tasked with examining the financial statements and responsible for the opinions he has given to the fairness of the financial statements. In conducting its audit, public accountants are guided by the International Standards on Auditing (ISA) issued by the International Auditing Practice Committee (IAPC) of the International Federation of Accountants (IFAC), complying with the code of Professional accountant of Indonesian Accountant Association (IAI) and Code of Ethics of Public Accountants from Indonesian Institute of Certified Public Accountants (IAPI), as well as complying with quality control standards. However, in practice, what happens today is that many public accountants do their job, not by existing standards, so that the quality of audits produced becomes questionable by the users of financial statements. 
In 2018, the Financial Profession Development Center (P2PK), as a supervisor of public accountants and public Accountant office, has issued five decrees on freezing sanctions permit public accountants including for public accountants Meilina Pangaribuan, Leader of KAP Dra. Meilina Pangaribuan, M.M. In Medan, ordinary public accountant Sitepu, Drs KAP leader, ordinary Sitepu in Medan, public accountant Hans Burhanuddin Makarao, leader of KAP Dra. Ellya Noorlisyati \& Co-branch of Palembang, public accountant James Pardomual Sitorus, who is a colleague of the Heliantono KAP \& a colleague in Jakarta and the last public accountant A. Krisnawan Budipracoyo, leader of KAP Krisnawan Nugroho \& Fahmi in Jakarta.

The cause of freezing the public accountant's license cases above is almost the same as not fully obtaining sufficient and precise audit evidence and has not fully adhered to the professional code of ethics in terms of accepting and implementing the Audit Alliance. This proves that the proof of audit and enforcement of the Code of Ethics has a determination in determining the quality of audit produced by the Public Accountant Office (KAP). Not only a small HOOD, even one of the Big 4 KAP, KAP Satrio Bing, Eny and Rekan (Deloitte Indonesia) penalized by OJK (Financial Services Authority) on October 1, 2018, because it has given opinions that do not reflect the condition The actual company to audit the financial statements of PT. Sunprima Nusantara Financing (SNP Finance). OJK impose sanctions on registration cancellation in AP Marlinna, AP Merliyana Syamsul, and KAP Satrio Bing, Eny, and Rekan. The Imposition of sanctions against AP and KAP by OJK Given that the audited annual financial report (LKTA) is used by the PT SNP to obtain credit from the banking and issue an MTN that has potentially failed to pay and/or become a credit Problematic. So that the OJK decisive step is an effort to maintain public confidence in the financial services industry.

In addition to the above phenomena, the office of Public Accountant in the city of Bandung has also had a similar case, such as the initials public Accountant SP, which is based on the decree of the Minister of Finance number: 704/KM. 1/2008 dated 22 October 2008 Frozen permission For six months due to violations of the SPAP. Other public accountants are suspended by the permission of the initials public Accountant ERS who committed a breach of the SPAP in conducting an audit on the financial statements of PT Dana Pensiun Pos Indonesia (Dapenpos) for the year ended 31 December 2007. In the field of audits, it takes great devotion to society and high moral commitment. The public demands to acquire the services of public accountants with high standards of quality, and demands that they are willing to sacrifice themselves. That is why the auditor profession establishes the ethical standards to be guided by the auditors in implementing the audit called the Code of Ethics. The code of Ethics or the ethical rules of the audit profession provides guidance for professional auditors in defending themselves from temptation and in making difficult decisions. The reason for such a high expectation of ethical application for professionals is the need for public trust in the quality of service provided by these professionals. As a professional, public accountants should be aware of the responsibility of the public, on clients, and in fellow practitioners, including proper conduct, even if it has to sacrifice personal interests. 


\section{Literatur Reviews}

\subsection{Internasional Standards on Auditing}

Auditing standards are general guidelines to assist auditors in fulfilling their professional responsibilities in the auditing of historical financial reports. Within the Audit, the standard includes professional quality considerations such as competency and independence requirements, reporting, and proof of Audit. The Indonesian Institute of Public Accountants (IAPI), as a professional organization, is obliged to establish audit standards. With developments occurring in the era of globalization, IAPI has decided to adopt International Standards on Auditing (ISAs) published by the International Auditing Practice Committee (IAPC) of the International Federation of Accountants ( IFAC) and thus do not impose any further audit standards that have been effective. The Association of Indonesian Public Accountants translates International Standards on Auditing (ISAs) into Bahasa Indonesia and is titled as a professional standard of public Accountant (SPAP) and establishes the enforcement of the professional standards of public accountants in Indonesia. As of 1 January 2013, public accountants in Indonesia are obliged to audit the financial statements based on the new standards.

\subsection{Proof of Audit}

The definition of proof of audit according to IAPI in SPA 500 is: "The information used by the auditor to conclude an auditor's opinion base. Proof of audit is considered quality if the evidence is relevant and reliable in support of the conclusion that is used as the auditor's opinion base. " The provisions of the audit evidence according to the IAPI in SPA 500 are as follows: (1) sufficient and precise audit proof that the Auditor shall design and implement appropriate audit procedures under the circumstances to obtain adequate and precise audit evidence; (2) information used as proof of audit at the time of designing and implementing the audit procedure, the Auditor shall consider the relevance and reliability of the information used as proof of audit, if the information used as proof of audit has been compiled using the work of management experts, auditors, to the extent necessary to consider the significance of the expert work for Auditors, by (a) evaluating the competencies, capabilities, and objectivity of such specialists; (b) Obtain an understanding of expert work; (c) Evaluate the suitability of the expert's work as proof of audit for relevant assertions. At the time of using the information generated by an entity, the auditor must evaluate whether the information is reliable for the auditor, including, if relevant, in a situation to: (a) obtain proof of audit of the accuracy and completeness Information (b) Evaluate whether the information is reasonably accurate and detailed to meet the auditors ' objectives; (3) The selection of elements for testing in obtaining the audit proof is when designing the test of control and detailed testing, the auditor must determine how the element selection for effective testing in achieving the objectives of the audit procedure; and (4) inconsistency or doubt on the disreliability of the audit evidence, two underlying conditions are (a) proof of audit obtained from a source contrary to proof of audit obtained from other sources; Or management refuses to correct some or all of the presentation errors communicated by the auditor, the auditor must obtain an understanding of the reasons for management not to make corrections and should take the Time evaluates whether the overall financial statements are free from misrepresentation of material; (b) Auditors have doubts about the reliability of the information used as proof of audit. Auditors must determine 
the modification or additional audit procedures necessary to resolve the issue and consider the impact, if any, of other aspects of the audit.

\subsection{Public Accountant Code of ethics}

The Indonesian Institute of Public Accountants adopted the code of the Handbook of Code Ethics for Professional Accountants published by the Internationa Ethical Standards Board for Accountants, this code of conduct describes the code of ethics as a line of Fundamental principles of Professional ethics and conceptual frameworks for the application of such principles. The code consists of three parts. Part A establishes the fundamental principles of professional ethics for each CPA and provides a conceptual framework that CPA must handle to (a) identify various threats to adherence to the fundamental principles of professional ethics; (b) Evaluating the signification of the various identified threats; and (c) to enforce security, when necessary, to eliminate or mitigate such threats to an acceptable level. While section $\mathrm{B}$ and part $\mathrm{C}$ explain the application of conceptual frameworks in certain situations, each CPA must adhere to the following fundamental principles of profession Ethics: (a) integrity, namely to be firm and honest in all professional relationships and business relationships; (b) Objectivation, i.e., not allowing bias, conflict of interest, or undue influence of the other party, which may affect the professional consideration or consideration of its business; (c) Professional care and competence, which is to have professional knowledge and expertise at the level necessary to ensure that the client or employer will receive competent professional services based on the development of practices, and conduct, and act seriously and by the methods of performing the work and professional standards in force; (d) Confidentiality, i.e., maintaining the confidentiality of information obtained as a result of a professional relationship and business relationship by not disclosing such information to a third party without the consent of the client or employer, except There is a legal obligation or professional right to disclose, and not to use the information for his or her personal or third party benefit; (e) Professional conduct, that is to comply with applicable regulatory legislation and to avoid any behavior that reduces the belief in the profession.

\subsection{Audit Quality}

In practical literature, the quality of audits is how appropriate the audit is with auditing standards, and on the other hand, accounting researchers identify various dimensions of audit quality. These different dimensions make the definition of audit quality also vary. There are four audit quality definition groups identified in the accounting literature: (1) Audit quality as the probability of the market- Financial statements containing material errors and auditors will find and report the error (2); (2) Audit quality is the probability that auditors will not report an Audit report with unexempted reasonable opinion for financial statements containing material misrepresentation $(3,4)$; (3) The quality of Audit is measured by the accuracy of information reported by auditors (5); and (4) The quality of Audit is determined by the ability of the audit to reduce noise and bias and increase the purity (fineness) of accounting data (6). Quality audits will be able to reduce the uncertainty factors related to the financial statements presented by the management. Continuous improvement over the quality of the audit should be done because it is natural if then the quality of audit is a topic that always gained deep attention from the profession of accountants, governments, and communities as well as investors. One thing is the problem in determining how to assess the quality of the audit, because the result of the quality of audit can not be directly observed and 
the quality of the audit has a different meaning between the individual. In connection with the quality of audits that cannot be observed directly then the researchers are looking for a replacement indicator of the quality of the audit, such as asking the expert opinion to determine the input-output of the audit quality or based on the number of Client. The quality of audit can be outlined into seven indicators, namely (7): (a) Skill; b Experience (c) Ethical value; (d) Mindsets; (e) Reliability of audit methods; (f) Effectiveness of tools used; (g) The existence of technical support.

\subsection{Influence of proof of Audit and enforcement of ethical code of Audit quality}

Agency Theory is an implementation in modern organizations. Agency theory emphasizes the importance of corporate owners (shareholders) handing over the management of the company to professionals called agents who are more understanding in conducting their daily business. The purpose of the management of the company's ownership is that the company's owners make the most profit as much as possible with the cost as efficiently as possible by the company by the professional personnel. Agency theory states that the need for independent services of the auditor can be explained by the basis of the agent theory, namely the relationship between the owner (principal) with the management (agents). With the development of companies or business entities that are increasingly larger, it is often the conflict between the principal, in this case, are the shareholders (investors) and the agents represented by the management (the Board of Directors). The assumption that the management involved in the company will always maximize the value of the company is not always fulfilled. Management has a personal interest that contradicts the interests of the owner of the corporation so that arises problems called agency problems as a result of asymmetric information (8). To reduce the existence of this agency is required an independent party that can be a mediator in dealing with the conflict known as a public accountant. There is a separation between the owners and the Managers/agents) of the company. This raises the needs of people over the auditor profession. Auditors are considered as independent parties between agents as information providers (financial statements) and stakeholders as users of information, thereby reducing information asymmetry (9-11).

Proof of audit consists of supporting evidence and proof of reinforcement, in the concept of proof of audit considered quality if the evidence is relevant and reliable in support of the conclusion of the auditor's opinion base, in addition to the results of research (12) states that proof of audit has direct implications for working paper and the quality of audit which means that it shows more reliable proof of audit, then the quality of the resulting audit is increasing, in other words, the proof of audit is proportional With quality audits. IAPI, as one of the public Accountant professional organizations Indonesia establishes and publishes a new public Accountant profession Code of Ethics and is active on 1 January 2019. Each auditor is also expected to uphold the professional ethics established by the Indonesian Institute of Public Accountants. Professional ethics can be interpreted as a rule or guideline that distinguishes between things to do and what not to do, the fundamental principles of professional ethics must be complied with by all who want to work as an independent auditor or Public accountant because auditors have the responsibility of the society. Therefore, in order to maintain the Community's trust in the services provided by the independent auditor, the Code of ethics is inevitable because they will play a lot in the activities posed by the client, Result from research Sawitri et al., 2015 (13) stated that the professional ethics code has a 
positive influence on the quality of the audit to be produced. From the above description and the scheme of thought frameworks, the hypothesis in this study is:

H1: Proof of Audit affecting the quality of Audit

H2: Implementing a code of conduct affects Audit quality

H3: Proof of Audit and implementation of the Code of ethics affects Audit quality

\section{Research Model, Hypotheses, and Methodology}

\subsection{Design Research}

The research method is a scientific way to obtain data with specific purpose and usability (14). The research method used in this study, if viewed from its exploratory level, is descriptive and associative. A descriptive method is a method used to describe or analyze a research result but is not used to make a broader conclusion. The associative method is research that seeks the relationship of influence between independent of the dependent variable.

\subsection{Types and sources of research funds}

This research uses cross-sectional data types. Cross-sectional data is the type of data that is taken at a specific time (one shoot time) within a limitation that corresponds to a specific measuring attribute. The data source used is the primary data source, primary data, which is data derived from respondents, both individuals and groups; this data is usually collected with instruments in the form of questionnaires or material interviews (15).

\subsection{Population and samples}

The population is a collection of elements that have specific characteristics that can be used to make conclusions. As for the population in this research of public accountants practicing in the city of Bandung with a total of 54 public accountants. The samples are a collection of subjects representing the population. The samples taken must have the same characteristics as the population and must represent (representative) of the populations. The sampling technique used is a census sampling technique; the census is the overall retrieval technique of population members (15).

\subsection{Variable operations}

As for providing an overview of the variables studied, the following table operationalization presented the following variables:

Table 1 Operationalization variables

\begin{tabular}{lllc}
\hline \multicolumn{1}{c}{ Variables } & \multicolumn{1}{c}{ Definition } & \multicolumn{1}{c}{ Indicators } & Scale \\
\hline Proof of Audit & Proof of Audit is the information & Adequacy of proof of Audit & Ordinal \\
$\left(\mathrm{X}_{1}\right)$ & used by the auditor in & Accuracy of proof of Audit & \\
\hline
\end{tabular}




\begin{tabular}{|c|c|c|c|}
\hline & $\begin{array}{l}\text { concluding an auditor's opinion } \\
\text { base (SA 500) }\end{array}$ & & \\
\hline $\begin{array}{l}\text { Code } \\
\left(\mathrm{X}_{2}\right)\end{array}$ & $\begin{array}{l}\text { The Code of Ethics provides an } \\
\text { outline of the fundamental } \\
\text { principles of professional ethics } \\
\text { and conceptual framework for } \\
\text { the implementation of the } \\
\text { principle (public Accountant } \\
\text { Code of ethics) }\end{array}$ & $\begin{array}{l}\text { Integrity } \\
\text { Objectivity } \\
\text { Professional prudence and } \\
\text { competence } \\
\text { Confidentiality } \\
\text { Professional behavior }\end{array}$ & Ordinal \\
\hline $\begin{array}{l}\text { Audit Quality } \\
\text { (Y) }\end{array}$ & $\begin{array}{l}\text { Audit quality is determined by } \\
\text { the ability of auditing to reduce } \\
\text { noise and bias and to improve } \\
\text { fineness in the data of } \\
\text { Accountants (6) }\end{array}$ & $\begin{array}{l}\text { Skill } \\
\text { Mindset } \\
\text { Reliability of Auditing } \\
\text { methods } \\
\text { The effectiveness of tools } \\
\text { used } \\
\text { Technical support }\end{array}$ & Ordinal \\
\hline
\end{tabular}

\subsection{Data Analysis Techniques}

The data obtained will be analyzed which are affected by (1) quality testing of the research instrument, considering that the research data is the primary data so that it needs to be conducted testing the quality of research instruments consisting of: (a) validity test and (b) Test of Reliability; (2) Multiple regression analysis with the following equation: $\mathrm{Y}=\mathrm{a}+\beta_{-} 1$ $\mathrm{x} \_1+\beta \_2 \mathrm{x} \_2+\varepsilon$ Where:

Y: Quality Audit

$\alpha$ : Important value (constant)

$\beta 1 \ldots \beta 3$ : Coefficient of regression direction

X1: proof of Audit

X2: Enforcement of Code of ethics

$\varepsilon$ : Error Rate

To analyze the effect of the audit-proof variable (X1) and the enforcement of the Code of Ethics (X2) on the quality of audit (Y) used statistical method with the level of significance $\alpha$ $=0.05$ means the degree of error by $5 \%$. 


\section{Result and Discussion}

\subsection{Research results}

In this study, the author shared a questionnaire of 54 questionnaires at the 31 public Accountant office in Bandung. The questionnaire consisted of 30 questions, where ten questions about proof of audit, ten questions about the enforcement of the code, and ten questions about the quality of the audit. Of the total questionnaire that was spread over 54 questionnaires, as for the return questionnaire was 30 questionnaires from 14 public accountant offices in the city of Bandung with a return rate of $55.55 \%$. Because 17 public accountant offices refused to receive questionnaires. According to Cooper and Schindler (14) states: "With a return rate of $30 \%$ is included well, and it would be better when it reaches $70 \% "$. Thus, the questionnaire return rate of $55.55 \%$ is sufficient to return to qualify for the data to be processed. In a study, the data used must be valid which means the instrument used can measure the variables in question. The minimum requirement to meet valid criteria is if the Rtabel $=0.361$, so if the $\mathrm{R}$ count is below 0.361, then it can be concluded that the instrument is not valid, so it should be repaired, the result of the validity test is as follows:

Table 2 Results proof variable validity of Audit test (X1)

\begin{tabular}{cccc}
\hline $\begin{array}{c}\text { Inquiry } \\
\text { Number }\end{array}$ & \multicolumn{2}{c}{ Correlation Product Moment } & \multirow{2}{*}{ Description } \\
\cline { 2 - 3 } & $\mathbf{r}$ count & $\mathbf{r}$ table & \\
\hline 1 & 0,564 & 0,361 & Valid \\
\hline 2 & 0,758 & 0,361 & Valid \\
\hline 3 & 0,495 & 0,361 & Valid \\
\hline 4 & 0,716 & 0,361 & Valid \\
\hline 5 & 0,815 & 0,361 & Valid \\
\hline 6 & 0,815 & 0,361 & Valid \\
\hline 7 & 0,815 & 0,361 & Valid \\
\hline 8 & 0,532 & 0,361 & Valid \\
\hline 9 & 0,594 & 0,361 & Valid \\
\hline 10 & 0,564 & 0,361 & Valid \\
\hline
\end{tabular}

Table 3 Results Validity test of the Code Enforcement of Ethics (X2)

\begin{tabular}{cccc}
\hline Inquiry & \multicolumn{2}{c}{ Correlation Product Moment } & \multirow{2}{*}{ Description } \\
\cline { 2 - 3 } Number & r count & r table & \\
\hline 1 & 0,684 & 0,361 & Valid \\
\hline 2 & 0,791 & 0,361 & Valid \\
\hline 3 & 0,868 & 0,361 & Valid \\
\hline 4 & 0,801 & 0,361 & Valid \\
\hline 5 & 0,636 & 0,361 & Valid \\
\hline 6 & 0,732 & 0,361 & Valid \\
\hline 7 & 0,777 & 0,361 & Valid \\
\hline 8 & 0,441 & 0,361 & Valid \\
\hline 9 & 0,718 & 0,361 & Valid \\
\hline
\end{tabular}




\begin{tabular}{llll}
\hline 10 & 0,633 & 0,361 & Valid \\
\hline
\end{tabular}

Table 4 Results validity test variable quality Audit (Y)

\begin{tabular}{cccc}
\hline \multirow{2}{*}{$\begin{array}{c}\text { Inquiry } \\
\text { Number }\end{array}$} & \multicolumn{2}{c}{ Correlation Product Moment } & \multirow{2}{*}{ Description } \\
\cline { 2 - 3 } & r count & r table & \\
\hline 1 & 0,775 & 0,361 & Valid \\
\hline 2 & 0,663 & 0,361 & Valid \\
\hline 3 & 0,489 & 0,361 & Valid \\
\hline 4 & 0,412 & 0,361 & Valid \\
\hline 5 & 0,577 & 0,361 & Valid \\
\hline 6 & 0,608 & 0,361 & Valid \\
\hline 7 & 0,714 & 0,361 & Valid \\
\hline 8 & 0,740 & 0,361 & Valid \\
\hline 9 & 0,610 & 0,361 & Valid \\
\hline 10 & 0,549 & 0,361 & Valid \\
\hline
\end{tabular}

While reliability tests are aimed at knowing the consistency of the measuring instrument, whether the measuring device is used is reliable and remains consistent if the measurement is repeated. As for the reliability testing is as follows:

Table 5 Realibiltas Test

\begin{tabular}{lcl}
\hline \multicolumn{1}{c}{ Variable } & $\begin{array}{c}\text { Cronbach's } \\
\text { Alpha }\end{array}$ & Decision \\
\hline Variable proof of Audit (X1) & 0,863 & Realibel \\
\hline $\begin{array}{l}\text { Variable enforcement of ethical code } \\
(\mathrm{X} 2)\end{array}$ & 0,890 & Realibel \\
\hline Audit quality variable (Y) & 0,816 & Realibel \\
\hline
\end{tabular}

Based on the results of the above data processing, it appears that Cronbach's Alpha value is obtained from all three variables above Cronbach's Alpha $>0.60$, so it can be concluded that the entire variable is reliable. Double regression analysis is used by researchers when researchers intend to predict how the state (ups and downs) of dependent variables when two or more independent variables as predictor factors are manipulated (To lower its value). The regression analyses used in this study were double linear regression of two predictors. The results of multiple regression tests are as follows: 
Table 6 Multiple regression analysis

Coefficients

\begin{tabular}{|c|c|c|c|c|c|c|}
\hline \multirow{2}{*}{\multicolumn{2}{|c|}{ Model }} & \multicolumn{2}{|c|}{ Unstandardized Coefficients } & \multirow{2}{*}{$\begin{array}{c}\text { Standardized } \\
\text { Coefficients } \\
\text { Beta }\end{array}$} & \multirow[t]{2}{*}{$\mathrm{t}$} & \multirow[t]{2}{*}{ Sig. } \\
\hline & & B & Std. Error & & & \\
\hline \multirow{3}{*}{1} & (Constant) & 9.741 & 6,423 & & 1.566 & .129 \\
\hline & Proof of Audit & .508 & .154 & .559 & 3.307 & .003 \\
\hline & $\begin{array}{l}\text { Enforcement of ethical } \\
\text { code }\end{array}$ & .079 & .136 & .098 & .582 & .566 \\
\hline
\end{tabular}

Based on the table above known value constants and regression coefficient, so that can be formed equation of multiple linear regression as follows: $\mathrm{Y}=9,741+0,508 \mathrm{X} \_1+0$, 079X_2. The equation can be interpreted as follows: (1) $\alpha=9,741$ meaning if the X1 and X2 variables are 0 , then the $Y$ variable will be worth 9.741 units; (2) $\beta 1=0,508$ it means that if it increases by 0.508 and the other variable is constant, then the variable $\mathrm{Y}$ will increase by 0.508 units; (3) $\beta 2=0,079$ means if it increases by 0.079 and the other variable is constant, then the $\mathrm{Y}$ variable will increase by 0.079 units, the correlation test is used to know the strength or absence of the relationship between the free variables and the bound variables When expressed with a linear function and measured by a value called the correlation coefficient. The correlation test results in this study can be seen in the following table:

Table 7 Coefficient of determination

Model Summary

\begin{tabular}{lcccc}
\hline Model & R & R Square & $\begin{array}{c}\text { Adjusted R } \\
\text { Square }\end{array}$ & $\begin{array}{c}\text { Std. The error of } \\
\text { the Estimate }\end{array}$ \\
\hline 1 & $.539^{\mathrm{a}}$ & .291 & .238 & 4.62385 \\
\hline a. Predictors: (Constant), Bukti Audit, Penegakan Kode Etik & \\
\hline b. Dependent Variable: Kualitas Audit & & \\
\hline
\end{tabular}

Based on the table above, it can be noted that the correlation coefficient value $(R)$ is 0.539. Based on the value it indicates that there is a relationship between the free variable and the bound variable, while the adjusted value of $\mathrm{R}$ Square 0.238 indicates the simultaneous influence of the proof of Audit variable and the implementation of the Code of ethics The Audit quality is $23.8 \%$ while the rest is influenced by other factors outside of the research model.

\subsection{Discussion}

In the results of the study obtained descriptive analysis results that the audit evidence on the KAP of Bandung has an average score of 4.207 included in the category is very good, where the results are in the range of classification criteria between $\geq 4.21$ and $\leq 5.00$ because Both indicators (1) adequacy of the Audit Proof and (2) The accuracy of the Audit evidence obtain an outstanding and good category. Based on these results, it can be concluded that the 
audit proof obtained by KAP Kota Bandung has been included very well. The results of data processing indicate that the first hypothesis can be received due to the sig value of 0.003 , which means there is an influence of proof of audit on the quality of the audit. The results of this study are in line with previous research conducted by (Bennett \& Hatfield, 2013) which says that the audit-proof is positive and significant to the quality of the audit (12). The results of this research show that the audit proof obtained by a Public Accountant in Bandung City affects the quality of audit produced by KAP Kota Bandung. Proof of Audit is one of consideration of public accountant in issuing audit opinion. Adequate and precise material evidence is needed by public accountants to detect any irregularities occurring in a financial statement. The audit is said to be qualified if the audit results are free from any form of deviation and by the audit standards set.

In the results of the research obtained descriptive analysis that the enforcement of the Code of Ethics on the KAP Bandung City gained an average score of 3.660 included in the category of good, where the results are in the range of classification criteria between $\geq 3.41$ and $\leq 4.20$ because The five indicators are (1) integrity, (2) objectivity (3) Prudence and professional Competence, (4) confidentiality, and (5) Professional attitudes obtain an excellent and adequate category. Based on these results, it can be concluded that the enforcement of the code of Conduct on the KAP Bandung city is already included. The result of data processing indicates that the second hypothesis failed player by the data or in other words the hypothesis is unacceptable due to the SIG's value of 0.556 which means there is no influence on the enforcement of the code of conduct of audit quality, The results of this study were not in line with previous research conducted by Sawitri et al, (2015), that indicates that the enforcement of the code tends to be less concerned by public accountants who are surveyed when compared to the proof of audit but the actual enforcement of the code may not be ruled out because it shows the moral responsibility of Public accountants in account of the audit results given in the form of an audit opinion that will ultimately impact the quality of the audit provided (13).

Based on the result of the correlation calculation obtained, a correlation value of 0.539 , meaning proof of audit and enforcement of the Code of Ethics, has a relation to the quality of audit on the KAP of Bandung. Then in the result of the tested coefficient of determination obtained the value of the coefficient of determination or Adjusted R-square by $23.8 \%$, wherein the audit-proof variable (X1) and the enforcement of the Code of Ethics (X2) have a simultaneous influence on the audit quality variables (Y). The results of this study also showed that the respondents studied were more likely to pay attention to the audit evidence than the enforcement of the code. Public accountants must be able to obtain adequate and precise audit evidence as a basis for the retrieval of their opinion, and also public accountants are also required to adhere to the code of Ethics and pay attention to the code of Ethics in accepting and implementing the Audit Alliance So that it will support public accountants in producing good audit quality.

\subsection{Conclusion}

Based on the results of research discussion on the influence of proof of audit and enforcement of ethical code on the quality of audit on the KAP of Bandung City, then the research results can be concluded as follows: (1) based on the results of research obtained Audit affects the quality of audits; (2) The enforcement of ethical code does not significantly affect the audit quality; and (3) The proof of the audit and enforcement of ethical code simultaneously affects the audit quality of $23.8 \%$. The results of this research imply that there 
are still public accountants who are less concerned with moral responsibilities and more focused on the technical things in favor of the opinions that will be given.

\section{References}

1. Iswari TI. The Effect of Organizational-Professional Conflict towards Professional Judgment by Public Accountant Using Personality Type, Gender, and Locus of Control as Moderating Variables. Rev Integr Bus Econ Res. 2013;2(2):434-48.

2. DeAngelo LE. Auditor size and audit quality. J Account Econ. 1981;3(3):183-99.

3. Lee CJ, Liu C, Wang T. The 150-hour rule. J Account Econ. 1999;27:203-28.

4. Nugroho L, Wicaksono BR, Utami W. Analysis of Taxes Payment, Audit Quality and Firm Size to The Transfer Pricing Policy in Manufacturing Firm in Indonesia Stock Exchange. Int J Bus Soc. 2018 Sep 19;2(8):83-93.

5. Feltham GA, Hughes JS, Simunic DA. Empirical assessment of the impact of auditor quality on the valuation of new issues. J Account Econ. 1991;14(4):375-99.

6. Watkins AL, Hillison W, Morecroft SE. Audit Quality: A Synthesis of Theory and Empirical Evidence. J Account Lit. 2004;23:153-93.

7. Suseno NS. The Influence Of Independence, Size Of Public Accountant Office Toward Audit Quality And Its Impact On Public Accountant Office Reputation. 2013;2(3):123-6.

8. Utami W, Nugroho L. Potential Big Bath Accounting Practice in CEO Changes (Study on Manufacturing Companies Listed in Indonesia Stock Exchange). Int J Account Financ Stud. 2018;1(2):202-15.

9. Erik Nugraha, Lucky Nugroho RD. Seminar Nasional dan Diskusi Panel Multidisiplin Hasil. In: Seminar Nasional dan Diskusi Panel Multidisiplin Hasil Penelitian \& Pengabdian kepada Masyarakat. 2018. p. 165-70.

10. Jensen MC, Meckling WH. Theory of The Firm: Managerial Behavior, Agency Costs and Ownership Structure. J financ econ [Internet]. 1976 [cited 2019 Jun 26];3:305-60. Available from: http://117.211.153.211:8001/jspui/bitstream/123456789/335/1/1-s2.00304405X7690026X-main.pdf

11. Nugroho L, Nurrohmah S, Anasta L. Faktor-Faktor Yang Mempengaruhi Opini Audit Going Concern. J SIKAP (Sistem Informasi, Keuangan, Audit Dan Perpajakan). 2018;2(2):96.

12. Bradley Bennett G, Hatfield RC. The effect of the social mismatch between staff auditors and client management on the collection of audit evidence. Account Rev. 2013;88(1):31-50.

13. Nandari A, Latrini M. Pengaruh Sikap Skeptis, Independensi, Penerapan Kode Etik, Dan Akuntabilitas Terhadap Kualitas Audit. E-Jurnal Akunt. 2015;10(1):164-81.

14. Cooper DR, Schindler PS. Business Research Methods. Eleventh. New York-NY: McGraw-Hill Irwin; 2006.

15. Chandrarin G. Metode Riset Akuntansi. Jakata: Salemba Empat; 2017. 